Jurnal Health Sains: p-ISSN: 2723-4339 e-ISSN: 2548-1398

Vol. 2, No. 8, Agustus 2021

\title{
PENGARUH JENIS KARAGENAN TERHADAP KARAKTERISTIK FISIK GEL ANTI JERAWAT
}

\author{
Yuyun Nailufa, Yuli Ainun Najih, Dita Nurlita Rakhma \\ Universitas Hang Tuah Surabaya, Indonesia \\ Email: yuyun.nailufa@hangtuah.ac.id, yuli.najih@ hangtuah.ac.id, ditanurlitar@gmail.com
}

\begin{tabular}{|c|c|}
\hline INFO ARTIKEL & ABSTRAK \\
\hline $\begin{array}{l}\text { Diterima } \\
5 \text { Agustus } 2021 \\
\text { Direvisi } \\
15 \text { Agustus } 2021 \\
\text { Disetujui } \\
25 \text { Agustus } 2021\end{array}$ & $\begin{array}{l}\text { Jerawat (acne vulgaris) merupakan suatu penyakit yang ditandai dengan } \\
\text { peradangan pada kulit yang dapat menyebabkan infeksi kulit. Tujuan } \\
\text { penelitian ini adalah untuk Mengetahui pengaruh jenis karagenan } \\
\text { (kappa, iota dan lamda) terhadap karakteristik fisik gel anti jerawat. } \\
\text { Metode penelitian yang digunakan adalah metode kualitatif. Pada } \\
\text { penelitian ini dilakukan pembuatan sediaan gel dengan gelling agent }\end{array}$ \\
\hline $\begin{array}{l}\text { Kata Kunci: } \\
\text { karagenan; gel; tea } \\
\text { tree oil; melaleuca } \\
\text { alternifolia; anti } \\
\text { jerawat }\end{array}$ & $\begin{array}{l}\text { karagenan. Jenis karagenan yang digunakan yaitu kappa, iota dan lamda. } \\
\text { Konsentrasi yang digunakan sama yaitu } 1 \% \text {. Berdasarkan hasil } \\
\text { pengujian didapatkan bahwa gel yang memiliki karakteristik yang paling } \\
\text { baik yaitu mudah merata, jernih, lembut dan viskositas yang baik artinya } \\
\text { tidak terlalu encer dan tidak terlalu viskus adalah formula } 2 \text { dengan } \\
\text { gelling agent iota karagenan. Hasil formula } 1 \text { dengan gelling agent kappa } \\
\text { karagenan didapatkan gel yang kaku, kurang jernih dan sulit diratakan. } \\
\text { Sedangkan pada formula } 3 \text { dengan gelling agent lamda karagenan } \\
\text { didapatkan gel yang jernih namun encer. Berdasarkan hasil uji stabilitas } \\
\text { dari ketiga formula tersebut stabil dengan metode sentrifugsi dengan } \\
\text { kecepatan } 3000 \mathrm{rpm} \text { selama } 5 \text { jam. }\end{array}$ \\
\hline
\end{tabular}

\section{ABSTRACT}

Acne (acne vulgaris) is a disease characterized by inflammation of the skin that can cause skin infections. The purpose of this study was to find out the effect of karagenan types (kappa, iota and lamda) on the physical characteristics of anti-acne gels. The research method used is qualitative method. In this study conducted the manufacture of gel preparations with gelling agent karagenan. The types of karagenan used are kappa, iota and lamda. The concentration used is the same as 1\%. Based on the test results obtained that the gel that has the best characteristics that are easy to flatten, clear, soft and good viscosity means not too diluted and not too viscosic is formula 2 with gelling

Keywords:

karagenan; gel; tea tree oil; melaleuca alternifolia; anti acne agent iota karagenan. The results of formula 1 with gelling agent kappa karagenan obtained a gel that is stiff, less clear and difficult to flatten. While in formula 3 with gelling agent lamda karagenan obtained a clear but diluted gel. Based on the results of the stability test of the three formulas are stable with the centrifuge method with a speed of $3000 \mathrm{rpm}$ for 5 hours.

\section{Pendahuluan}

Jerawat merupakan masalah kulit yang sering ditemui pada remaja dan dapat menurunkan tingkat kepercayaan diri
(Agustiningsih et al., 2019). Jerawat merupakan suatu kondisi kulit yang tidak normal dimana terjadi infeksi dan radang pada kelenjar minyak di kulit (Kusbianto et

$\begin{array}{ll}\text { How to cite: } & \text { Nailufa, Y., Najih, Y. A., Rakhma, D. N. (2021) Pengaruh Jenis Karagenan terhadap Karakteristik } \\ & \text { Fisik Gel Anti Jerawat. Jurnal Health Sains 2(8). https://doi.org/10.46799/jhs.v2i8.257 } \\ \text { E-ISSN: } & 2723-6927 \\ \text { Published by: } & \text { Ridwan Institute }\end{array}$


al., 2018). Salah satu pemicu tumbuhnya jerawat adalah produksi sebum yang berlebihan (Zouboulis et al., 2014). Menurut Han $\mathrm{C}$ et al. pemakaian masker selama pandemi Covid 19 ini juga menjadi salah satu pemicu tumbuhnya jerawat karena pada area yang menggunakan masker sirkulasi udara menjadi terhambat dan kelembaban meningkat (Gomolin et al., 2020; Han et al., 2020).

Terapi jerawat dapat menggunakan sediaan topikal anti jerawat. Di pasar, obat antibakteri oral tersedia, tetapi kerugian dari formulasi oral lebih banyak daripada topikal (Orchard \& van Vuuren, 2017). Sediaan topikal anti jerawat yang banyak beredar dipasaran adalah gel karena nyaman digunakan, terasa dingin, transparan sehingga dapat meningkatkan nilai aseptabilitas dan kepatuhan penggunaan (Rosen et al., 2014).

Gel merupakan sediaan topikal yang berupa sediaan semipadat yang terdiri dari bahan aktif yang terlarut atau terdispersi yang dibuat dari partikel anorganik kecil atau molekul organik besar yang terpenetrasi dalam suatu cairan (Kemenkes, 2018)

Pembuatan sediaan gel dipengaruhi oleh polimer pembentuk basis gel (gelling agent) dan konsentrasi basis gel (gelling agent). Basis gel yang digunakan pada penelitian ini adalah karagenan. Konsentrasi karagenan untuk untuk gel adalah 0,6-1\% (Rowe et al., 2009). Karagenan adalah senyawa yang diekstraksi dari rumput laut. Karagenan merupakan senyawa hidrokoloid yang dapat membentuk basis gel. Terdapat 3 jenis karagenan yaitu kappa karagenan, iota karagenan dan lamda karagenan. Jenis karagenan tentunya akan berpengaruh terhadap sistem basis gel yag dihasilkan. Basis gel akan berpengaruh terhadap karakteristik fisik sediaan gel dan berpengaruh pada laju pelepasan dan penetrasi suatu bahan aktif ke dalam kulit.

Bahan aktif anti jerawat yang digunakan yaitu tea tree oil. Tea tree oil merupakan minyak atsiri yang terdapat dalam tanaman Melaleuca alternifolia, dimana tea tree oil memiliki aktivitas sebagai antiinflamasi dan antiinfeksi sehingga dapat digunakan sebagi anti jerawat (Działo et al., 2016). Menurut Salvatori et al., tea tree oil memiliki aktivitas antimikroba 11 kali lebih kuat dibandingkan asam karbolat dan fenol (Salvatore et al., 2017).

Jerawat (acne vulgaris) merupakan suatu penyakit yang ditandai dengan peradangan pada kulit yang dapat menyebabkan infeksi kulit (Zaenglein et al., 2016). Pengobatan jerawat dapat dilakukan dengan memberikan sediaan topikal anti jerawat. Salah satu bahan aktif anti jerawat untuk sediaan topikal adalah tea tree oil. Tea tree oil memiliki aktivitas sebagai antibakteri, anti jamur dan anti inflamasi (Hammer, 2015). Menurut Salvatori 2017 tea tree oil memiliki aktivitas antimikroba 11 kali lebih kuat dibandingkan asam karbolat dan fenol (Salvatore et al., 2017). Sediaan topikal anti jerawat dapat berupa gel, cream ataupun salep. Gel realtif lebih disukai karena berwarna jernih sehingga tidak terlihat saat digunakan. Gel juga nyaman digunakan karena dingin dan mudah tidak berminyak. Faktor utama yang menentukan keberhasilan pembuatan gel adalah gelling agent.

Tujuan penelitian ini adalah untuk Mengetahui pengaruh jenis karagenan (kappa, iota dan lamda) terhadap karakteristik fisik gel anti jerawat.

Manfaat dari penelitian ini adalah memberi masukan dalam melakukan formulasi sediaan topikal gel dari gelling agent biota laut yang belum banyak dimanfaatkan.

\section{Metode Penelitian}

Peralatan yang digunakan dalam penelitian ini antara lain: Alat - alat gelas (Herma), Timbangan analitik (Fujitsu), pH meter Laqua, Viskometer (Brookfield), Centrifuge Health H-C-8 dan Hotplate (Fisher 
Scientific). Metode penelitian yang digunakan adalah metode kualitatif.

Bahan yang digunakan pada penelitian ini adalah tea tree oil, kappa karagenan, iota karagenan, lamda karagenan, Glycerin, Propilenglikol, Methyl paraben, Propyl paraben, Silbion, Parfum Aloe Vera, Aquadest.

Pembuatan gel dilakukan dengan membuat gel dengan formula yang berbeda pada jenis gelling agent yang digunakan. Formula 1 menggunakan kappa karagenan, Formula 2 menggunakan iota karagenan dan
Formula 3 menggunakan lamda karagenan sedangkan konsentrasinya dibuat sama yaitu $1,0 \%$ yaitu:

Tabel Formula dapat dilihat pada tabel 1 di bawah:

Tabel 1

Formula Gel

\begin{tabular}{ccccc}
\hline \multirow{2}{*}{ Komposisi } & \multirow{2}{*}{ Kegunaan } & \multicolumn{3}{c}{ \% b/b } \\
\cline { 3 - 5 } & Gelling agent & 1,0 & - & \\
\hline Kappa karagenan & Gelling agent & & 1,0 \\
\hline Iota karagenan & Gelling agent & & & 1,0 \\
\hline Lamda karagenan & Anti jerawat & 0,5 & 0,5 & 0,5 \\
\hline Tea tree oil & Humektan & 1 & 1 & 1 \\
\hline Glycerin & Kosolven & 10 & 10 & 10 \\
\hline Propilenglikol & Emolien & 0,5 & 0,5 & 0,5 \\
\hline Silbione & Pengawet & 0,1 & 0,1 & 0,1 \\
\hline Methyl paraben & Pengawet & 0,05 & 0,05 & 0,05 \\
\hline Propyl paraben & Parfum & 0,5 & 0,5 & 0,5 \\
\hline Parfum Aloe vera & Solven & 76,15 & 76,15 & 76,15 \\
\hline Aquadest & & & &
\end{tabular}

Proses pembuatan gel anti jerawat dengan karagenan ini menggunakan metode yang cukup sederhana. Karagenan dilarutkan dalam setengah bagian aquadest yang tertera dalam formula dimana aquadest tersebut dipanaskan terlebih dahulu. Digunakan air panas $\left(70^{\circ} \mathrm{C}\right)$ untuk melarutkan karagenan karena karagenan ini memang lebih larut dalam air panas. Masukkan air panas ke dalam mortir dan larutkan karagenan dalam air panas tersebut di dalam mortir sambil diaduk. Kemudian tambahkan silbion dan pengawet yang telah dilarutkan dalam propilenglikol dan terus diaduk. Setelah itu tambahkan glycerin, tea tree oil, sisa aquadest dan parfum sambal diaduk sampai homogen. Gel yang telah jadi kemudian dievaluasi karakteristik fisiknya untuk mengetahui mutu gel tersebut.

a. Organoleptis

Pengujian karakteristik gel diawali dengan uji organoleptis atau sering disebut uji secara visual. Pengujian ini meliputi pengamatan pada bentuk, warna dan bau.

b. Homogenitas

Homogen atau seragam merupakan salah satu syarat sediaan farmasi karena untuk memastikan bahwa kandungan bahan aktif ataupun bahan eksipien telah tercampur merata. Uji homogenitas biasanya dilakukan dengan penetapan kadar pada sediaan. Sedangkan untuk mengetahui homogenitas secara fisik dapat dilakukan dengan menggunakan objek 
glass. Pengujian dilakukan dengan pengamatan secara visual dengan mengambil sejumlah gel kemudian diratakan pada objek glass, apabila tidak ditemukan butiran kasar maka gel homogen (Borse \& Srivastava, 2019)

c. $\mathrm{pH}$

Pengujian $\mathrm{pH}$ harus dilakukan untuk mengetahui $\mathrm{pH}$ sediaan. Pengujian $\mathrm{pH}$ dilakukan dengan menggunakan $\mathrm{pH}$ meter. Tingkat keasamaan suatu sediaan juga dapat digunakan untuk mendeteksi adanya iritasi pada kulit (Borse \& Srivastava, 2019)

d. Daya Sebar

Kemudahan suatu sediaan topikal untuk diratakan pada kulit merupakan salah satu nilai aseptabilitas. Pengujian daya sebar dapat dilakukan menggunakan sepasang kaca transparan. Tuang $0,5 \mathrm{~g}$ gel pada kaca kemudian tutup dengan pasangannya dan tambahkan beban seberat 125 g kemudian ukur lebar daya sebar setelah 1 menit (Borse \& Srivastava, 2019)

e. Uji viskositas

Viskositas adalah kekentalan suatu sediaan. Viskositas sediaan semisolida dalam hal ini gel dapat dilakukan dengan alat viskosimeter (Brookfield) dengan mengatur spindel. Caranya sediaan dimasukkan ke dalam wadah gelas kemudian pilih spindle yang sesuai, pasang spindel, kemudian spindel yang telah dipasang diturunkan sehingga batas spindel tercelup ke dalam sediaan. Kecepatan diatur $20 \mathrm{rpm}$. Jalankan alat viskosimeter dan catat nilai viskositasnya.

f. Stabilitas Fisik

Stabilitas fisik gel diuji dengan menggunakan metode sentrifugasi. Sentrifugasi dilakukan dengan kecepatan $3800 \mathrm{rpm}$ selama 5 jam. Setelah 5 jam dilakukan pengamatan organoleptis dan homogenitas, $\mathrm{pH}$, daya sebar dan viskositas (Nurdianti, 2018).

\section{Hasil dan Pembahasan}

\section{a. Organoleptis}

Hasil pengamatan secara organoleptis dapat dilihat pada tabel 2:

\begin{tabular}{ccccc}
\hline Formula & Warna & Bau & Bentuk & Sensasi rasa \\
\hline F1 & $\begin{array}{c}\text { Kecoklatan,Tidak } \\
\text { jernih, terdapat } \\
\text { putih -putih }\end{array}$ & Harum & Gel & $\begin{array}{c}\text { Sangat } \\
\text { kental, kaku, } \\
\text { Dingin \& } \\
\text { tidak lengket }\end{array}$ \\
\hline F2 & Hecoklatan, & Harum & Gel & $\begin{array}{c}\text { Kental, } \\
\text { Dingin \& } \\
\text { Jernih, transparan }\end{array}$ \\
F3 & Harum & Cair & $\begin{array}{c}\text { Cair, Dingin } \\
\& \text { tidak } \\
\text { lengket }\end{array}$ \\
\hline & $\begin{array}{c}\text { Kecoklatan, } \\
\text { Jernih, transparan }\end{array}$ & & & \\
\hline
\end{tabular}

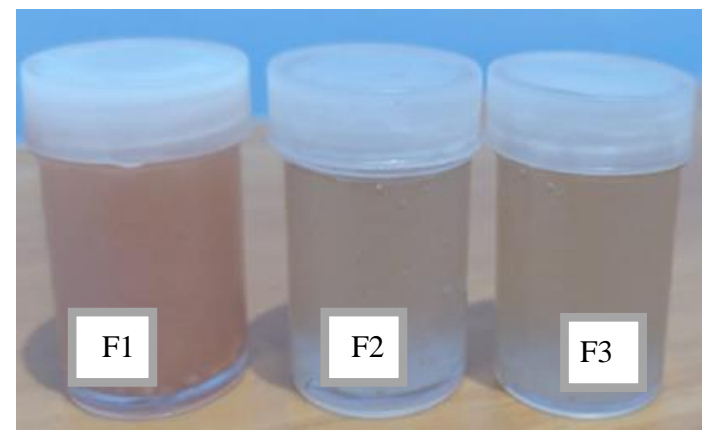

Gambar 1

Pengamatan organoleptis formula F1, F2 dan F3

b. Homogenitas

Hasil pengamatan pada homogenitas sediaan gel dapat dilihat pada tabel 3:

Tabel 3 Hasil Pengamatan Uji Homogenitas

\begin{tabular}{cc} 
Formula & Homogenitas \\
\hline F1 & Tidak homogen \\
\hline F2 & Homogen \\
\hline F3 & Homogen \\
\hline
\end{tabular}

c. $\mathbf{p H}$

Berdasarkan hasil uji $\mathrm{pH}$ didapatkan hasil pada tabel 4. Pada penelitian ini berdasarkan hasil uji $\mathrm{pH}$ didapatkan kesimpulan bahwa dari ketiga formula tersebut memberikan nilai $\mathrm{pH}$ yang tidak berbeda bermakna. 
Tabel 4

Hasil Uji pH

\begin{tabular}{cc}
\hline Formula & $\mathbf{p H}$ \\
\hline F1 & $6,8+0,02$ \\
\hline F2 & $6,5+0,01$ \\
\hline F3 & $6,6+0,02$
\end{tabular}

\section{d. Daya Sebar}

Daya sebar dilakukan untuk mengetahui bahwa sediaan tersebut mudah diratakan. Hasil pengujian daya sebar menunjukkan bahwa dari 3 formula terdapat perbedaan yang bermakna. Kappa karagenan menghasilkan nilai daya sebar yang lebih rendah bila dibandingkan dengan iota karagenan. Perbedaan jenis karagenan tersebuat ada pada ester 3,6anhydrogalactose dan ester sulfat dimana hal ini menyebabkan perbedaan pada kekuatan gel, tekstur dan sineresis. Kappa memiliki tipe gel kaku atau mudah rusak yang ditandai dengan sineresis tinggi, sementara iota memiliki gel yang elastis dan reversible (Suryani et al., 2019)

Tabel 5

Hasil Uji Daya Sebar

\begin{tabular}{cc}
\hline Formula & Daya Sebar $(\mathbf{c m})$ \\
\hline F1 & $2,45 \pm 0,044$ \\
\hline F2 & $6,21 \pm 0,040$ \\
\hline F3 & $10,52 \pm 0,80$ \\
\hline
\end{tabular}

e. Viskositas

Viskositas merupakan kekentalan suatu zat. Pengujian viskositas dilakukan dengan menggunakan viskosimeter (brookfield) dengan menggunakan spindel No. 50 dengan kecepatan $20 \mathrm{rpm}$. Pengujian viskositas dilakukan 2 kali yaitu saat awal dan setelah penyimpanan 1 bulan. Berdasarkan hasil penelitian dapat diambil kesimpulan bahwa ada perbedaan bermakna pada ketiga formula gel yang diuji. Hasil pengujiaan viskositas dapat dilihat pada tabel 6 dibawah ini:
Tabel 6

Hasil Uji Viskositas

\begin{tabular}{|c|c|c|}
\hline Formula & \multicolumn{2}{|c|}{ Viskositas Sediaan (c.Ps) } \\
\hline & Hari ke 0 & $\begin{array}{c}\text { Setelah } \\
\text { penyimpanan } 1 \\
\text { Bulan } \\
\end{array}$ \\
\hline F1 & 53350 & 53300 \\
\hline $\mathrm{F} 2$ & 12100 & 12080 \\
\hline F3 & 245 & 320 \\
\hline
\end{tabular}

Konsentrasi gelling agent menurut (Schorsch et al., 2000) sangat mempengaruhi viskositas gel. Kappa karagenan umumnya digunakan dalam rentang konsentrasi $0,5 \%-1,0 \%$ sebagai gelling agent dan $0,1 \%-0,5 \%$ untuk thickening agent. Iota dan lambda karagenan juga sering digunakan sebesar $0,1 \%-0,5 \%$ (Schorsch et al., 2000).

\section{f. Stabilitas}

Berdasarkan hasil uji stabilitas dapat diambil kesimpulan bahwa ketiga formula tidak mengalami perubahan karakteristik fisik secara bermakna sehingga dapat diambil kesimpulan bahwa ketiga formula tersebut stabil setelah dilakukan uji stabilitas.

\section{Kesimpulan}

Jenis karagenan berpengaruh terhadap karakteristik fisik dan stabilitas fisik gel tea tree oil. Dari ketiga formula dapat diambil kesimpulan bahwa iota karagenan dengan konsentrasi 1,0\% memiliki karakteristik fisik yang paling optimal. 


\section{BIBLIOGRAFI}

Agustiningsih, T., Pradanie, R., \& Pratiwi, I. N. (2019). Analisis Faktor Yang Berhubungan Dengan Kepercayaan Diri Akibat Timbulnya Acne Vulgaris Pada Remaja Berdasarkan Teori Adaptasi Roy Di Sma 17 Agustus 1945 Surabaya. Jurnal Keperawatan Muhammadiyah, 4(1). Google Scholar

Borse, V., \& Srivastava, R. (2019). Fluorescence Lateral Flow Immunoassay Based Point-Of-Care Nanodiagnostics For Orthopedic Implant-Associated Infection. Sensors And Actuators B: Chemical, 280, 24-33. Google Scholar

Działo, M., Mierziak, J., Korzun, U., Preisner, M., Szopa, J., \& Kulma, A. (2016). The Potential Of Plant Phenolics In Prevention And Therapy Of Skin Disorders. International Journal of Molecular Sciences, 17(2), 160. Google Scholar

Gomolin, T. A., Cline, A., \& Russo, M. (2020). Maskne: Exacerbation Or Eruption Of Acne During The Covid-19 Pandemic. Skin The Journal of Cutaneous Medicine, 4(5), 438-439. Google Scholar

Hammer, M. (2015). What Is Business Process Management? In Handbook On Business Process Management 1 (Pp. 316). Springer. Google Scholar

Han, C., Duan, C., Zhang, S., Spiegel, B., Shi, H., Wang, W., Zhang, L., Lin, R., Liu, J., \& Ding, Z. (2020). Digestive Symptoms In Covid-19 Patients With Mild Disease Severity: Clinical Presentation, Stool Viral Rna Testing, And Outcomes. The American Journal Of Gastroenterology. Google Scholar

Kemenkes, R. I. (2018). Hasil Utama Riskesdas 2018. In Online) Http://Www. Depkes. Go. Id/Resources/Download/InfoTerkini/Materi_Rakorpop_2018/Hasil\% 20riskesdas (Vol. 202018). Google Scholar

Kusbianto, D., Hamdana, E. N., \& Fahreza, D. D. (2018). Sistem Pendukung Keputusan Prioritas Calon Penerima Program Indonesia Pintar Pada Siswa Sekolah Menengah Pertama Menggunakan Metode Topsis. Jurnal Informatika Polinema, 4(2), 101. Google Scholar

Nurdianti, L. (2018). Evaluasi Sediaan Emulgel Anti Jerawat Tea Tree (Melaleuca Alternifolia) Oil Dengan Menggunakan Hpmc Sebagai Gelling Agent. Journal of Pharmacopolium, 1(1). Google Scholar

Orchard, A., \& Van Vuuren, S. (2017). Commercial Essential Oils As Potential Antimicrobials To Treat Skin Diseases. Evidence-Based Complementary And Alternative Medicine, 2017. Google Scholar

Rosen, J. E., Hancock, J. G., Kim, A. W., Detterbeck, F. C., \& Boffa, D. J. (2014). Predictors Of Mortality After Surgical Management Of Lung Cancer In The National Cancer Database. The Annals Of Thoracic Surgery, 98(6), 1953-1960. Google Scholar

Rowe, R. C., Sheskey, P., \& Quinn, M. (2009). Handbook of Pharmaceutical Excipients. Libros DigitalesPharmaceutical Press. Google Scholar

Salvatore, D. A., Weekes, D. M., He, J., Dettelbach, K. E., Li, Y. C., Mallouk, T. E., \& Berlinguette, C. P. (2017). Electrolysis Of Gaseous Co2 To Co In A Flow Cell With A Bipolar Membrane. Acs Energy Letters, 3(1), 149-154. Google Scholar

Schorsch, C., Carrie, H., \& Norton, I. T. (2000). Cross-Linking Casein Micelles By A Microbial Transglutaminase: Influence Of Cross-Links In AcidInduced Gelation. International Dairy Journal, 10(8), 529-539. Google 
Yuyun Nailufa, Yuli Ainun Najih, Dita Nurlita Rakhma

Scholar

Suryani, D., Nurdjanah, E. P., Yogatama, Y., \& Jumadil, M. (2019). Membudayakan Hidup Sehat Melalui Gerakan Masyarakat Hidup Sehat (Germas) Di Dusun Mendang Iii, Jambu Dan Jrakah Kecamatan, Tanjungsari, Gunungkidul. Jurnal Pemberdayaan: Publikasi Hasil Pengabdian Kepada Masyarakat, 2(1), 65. Google Scholar

Zaenglein, A. L., Pathy, A. L., Schlosser, B. J., Alikhan, A., Baldwin, H. E., Berson, D. S., Bowe, W. P., Graber, E. M.,
Harper, J. C., \& Kang, S. (2016). Guidelines Of Care For The Management Of Acne Vulgaris. Journal Of The American Academy of Dermatology, 74(5), 945-973. Google Scholar

Zouboulis, C. C., Jourdan, E., \& Picardo, M. (2014). Acne Is An Inflammatory Disease And Alterations Of Sebum Composition Initiate Acne Lesions. Journal Of The European Academy of Dermatology And Venereology, 28(5), 527-532. Google Scholar

\section{Copyright holder:}

Yuyun Nailufa, Yuli Ainun Najih, Dita Nurlita Rakhma (2021)

\section{First publication right:}

Jurnal Health Sains

This article is licensed under:

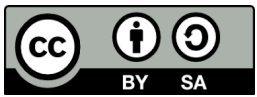

